Distrfbution Gategory:

Magnetic Pusion Energy (UC-20)

ABCONE MATIOHAL LABORATOKY

DE85 000779

9700 South Cass Avenue

Argome, Illinols 60439

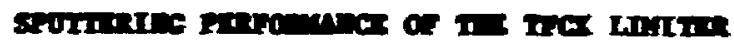

by

J. N. Brooks

.

Pusion Power Progra

September 1984

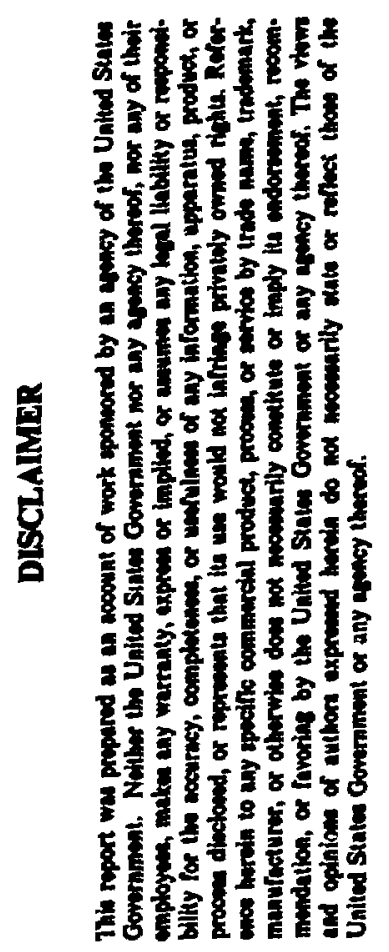




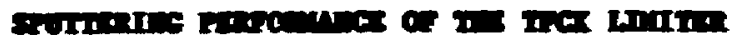

J. H. Exooke

Fustion Power Frogras

Argone Intionl Leboratory

Argonie, Illinot: 60439

\begin{abstract}
AnTrer
The eputtering perforance of the proposed IFC puped linter analyzed using the Roce computer code. Erosion, redeposition, surface shape and hent flux changes wth tine, and plasan contanination lasues were exinined. A carbon conted linfter was found to give acceptable sputterios perforance over the TPCX lifetive if, and only if, scceptable redeposition properties of carbon are obtalned.
\end{abstract}

\title{
1.0 Imosthria
}

The IFCX device, as a near term ignition wehine, has different inpurity control requirements than efther present derices or future adranced derices such as Irron. Compared to Irron, the erosion rate due to sputtering 1 much lese of an Istue simply becuse the avallability of ICX is wo wh lomer (17) compared to $50 \mathrm{z}$ ).

On the other hand, plawe contalnation from sputtered ateriel is sonewhat nore faportant for TrC afnce there is less of an ignition argin than for wore advanced axchines. Compared to present tokanaks, Tra would have longer pulse lengthe $(-100)$ and higher heat particle fluxes, all ankin the lesue of sputtering wore isportant. To eralunte these isaues, the spattering performance of the proposed botton lintter for IFC wa exenined, using the REDEP computer code. This code has been described eleerbere. (1) Irfefly, the code nodels the transport, lonization, and redepostion of aputtered aurface eaterial in the scrapeoff zone, plase, first mil, and liniter/divertor reglons of a toknak. The latest rersion of the code, Aabir4, follow the time evolution of the Iinter surface, and has other inprovenents in the nodels. 
The input to the now code consteted of plean profiles $\left(T_{e}, T_{I}, H_{e}\right.$, heat and particle fluxes), and charge exchange neutral sputtering fluxes. These were provided(2) by the 1-1/2 dinensional tranoport code waIst run in confunction with the neutral traneport code Diass. The rersion of the Irax design paracters uned here are $\mathrm{E}=3.25 \mathrm{M}, \mathrm{a}=1.31 \mathrm{M}, \mathrm{k}=1.6, \mathrm{I}_{\mathrm{p}}=10 \mathrm{KA}$, and an alpha pourer of $50 \mathrm{mH}$. The linter configuration eranined is a flat, toroldally continuous, angle-edge design, located at the botton of the torus. Carbon is the reference conting aterial.

As ofll be discussed, it is important for the we of carbon in MCX that redeposited carbon lon stck to the liniter surface and form a redeposteed surface having acceptable properties (adhesion, thermi conductivity, etc.). It Is assumed for the calculation that the redeposited carbon layer has the sane sputtering coefficients as the original conting. As discussed in Refs. 1 and 3 there is reason to question these assuaption, but relevant data for a better model is lacking. Also, except were otherwise indicated, only physical sputterlig was assuned, 1.e., chenteal sputtering was 1goored. This requires adequate control of the carbon contins temerature. The effect of varlations In edge condtions and costing aterials was also exanined.

\subsection{Msulhs}

For the reference conditions, the linter shape, net growth rate, and heat flux are shown In Figs. 1 through 3. Except for the leading edge, the Iiniter results are approxinately symetric about the liatter center, therefore results are shown for the left side only. In Fis. 1 , the coordinates $x$ and $y$ denote the anjor radius and elevation coordinates respectirely, with $x=$ $y=0$ denoting the center of the toknak. In Figs. 2 and 3 , 1initer points $2-$ 21 denote points on the front face Initially spaced $1.62 \mathrm{cl}$ apart, and points 22-26 denote leading edge points wich are Initially spaced 1.00 cu apart. The liniter shape at tine $t=0$ is prescribed as a flat top surface, with a $-1.5 \mathrm{~cm}$ radius leading edge. The botton side of the Iiniter is subject to less erosion and was not sodeled. As shown, the net grouth rate (redeposition einus sputtering) of the carbon surface, at $t=0$, varies fros $-7 \mathrm{co} / \mathrm{gr}$ at the leading edge to $-14 \mathrm{ca} / \mathrm{yr}$ on the top surface. The gross exosion rate (hydrogen + helfu + self-sputtering) at these two polnts is $93 \mathrm{~cm} / \mathrm{gr}$ and $179 \mathrm{~cm} / \mathrm{gr}$ respectively, thus redeposition is seen to be an important effect in reducing 


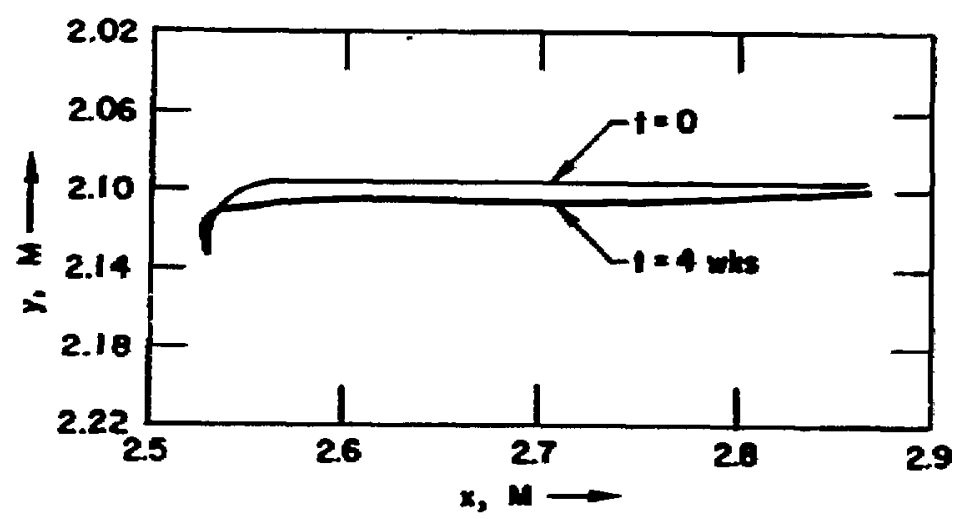

F18. 1. Ifiter shape at Initial startup and after four weeks of contlwous operetion.

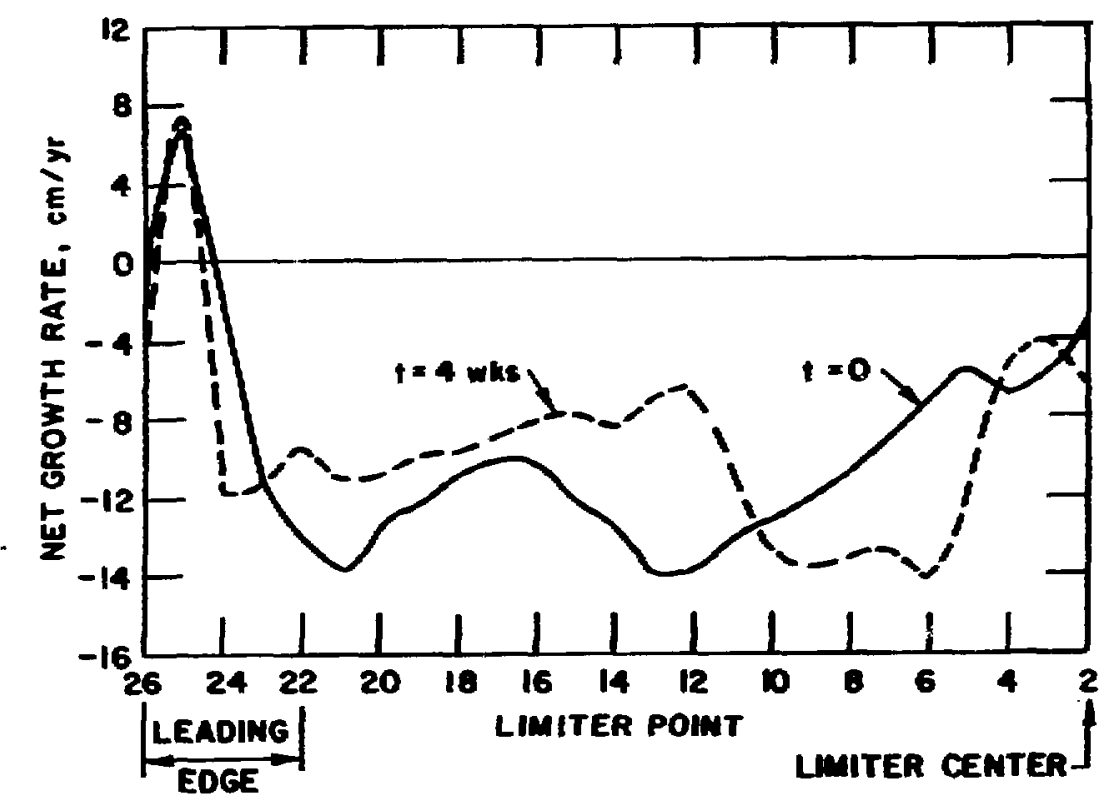

F15. 2. Het growth rate of the 11ater carbon coating et Initial startup and after four meke of continuoue operatior. 


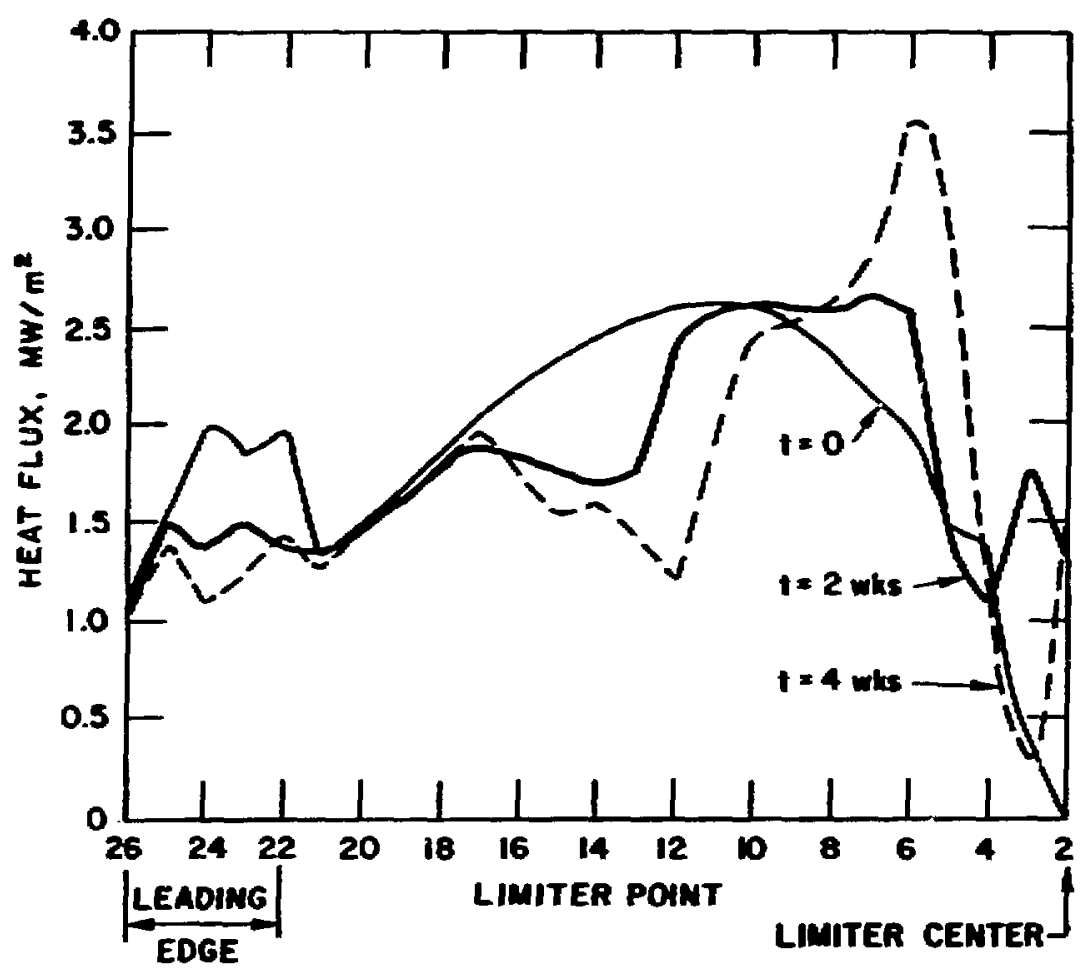

Fig. 3. Liniter heat flux at initial startup and after two and four weeks of continuous operation.

erosion. (All erosion rates quoted are for continuous operation; for device like TFCX having -17 availability, one reek of continuous operation is equivalent to about two calendar years.) The positive net growth rate over some of the leading edge is due to transfer of aterial from the front face. Since the net erosion rate is deternined by the difference between two fairly large tera (erosion and redeposition) the net rate is wodel dependent and can change vith variations in sucb parmeters as edge deneity, e-folding distances and angetic field line structure.

- Based on the predicted net growth rate, the code computes the change in the surface of the liniter. This was done at two-veek (continuous operation) interval. At each interval, the code computes the new particle flux, oputtering and redeposited distributions. At the end of four week the front surface of the liniter had eroded by about $1 \mathrm{ca}$. A seen from the net grouth profiles the limiter erosion is sombat self-compensating. Tis is, high 
erosion rate areas at $t=0$ tend to have lower net erosion at $t=4$ weeks, and vice versa.

The heat flux profile across the linter is sendtive to andi changes in shape. As a result, the heat flur profile changes subatantially with tine, as shown In $\mathrm{Fig}$ - 3. The peak beat flux is $-2.5 \mathrm{~m} / \mathrm{a}^{2}$ initialiy and rises to $-3.5 \mathrm{~m} / \mathrm{a}^{2}$ after four veeks. The latter value is acill probably acceptable.

Plasen contanination from sputterins depends on the fraction of sputtered carbon lonized in the scrapeoff zone. For the reference case, the contanination fraction, seff, defined as the ratio of the carbon aton current entering the plasen to the deuteriudtritiun ion current learins the plasen, 1 s 0.018 . ( $s^{\text {eff }}$ can also be thought of as the effective sputering coeffictent.) Iontzation and subsequent redeposition in the scrapeoff zone reduce the carbon flux entering the plasia by hout a factor of 5 . ThI remins nearly contant through four weeks of operation. The ohielding efficiency (see Ref. I) of the scrapeoff zone 18, therefore, $-80 \%$. If the carbon entering the placma had the same confinement tive as the D-T Ions, the carbon concentration, In steady gtate, would be equal to seff, 1.e. 1.87 of the D-T density. However, traneport code studies( 4 ) have show that the core plean Inpurity denetty should be substantially less than this value, due to high Ipurfty recyeling in the edge region. Although the transport atudles were done for a larger derice, a sinilar result would be expected for TFG. Based on a predicted factor of 4 difference In the Inpurity confinenent tine, the carbon concentration would be -0.5\%. This yalue is acceptably anll.

In the event, however, that redeposited carbon lons do not adequately stick to the liniter surface, the resulting carbon concentration in the plasas would appear to be intolerable. For this case, and in the absence of any other rewoval nechantsm, the bufldup of carbon in the plase can be written as:.

$$
\frac{d}{d t} \frac{N_{z}}{N_{D I}}=\frac{s^{e f f}}{\tau},
$$

where $\mathrm{K}_{\mathrm{Z}}$ and $\mathrm{N}_{\mathrm{DT}}$ are the average carbon and deuteriun denetties in the plasas, and $\tau$ is the D-T particle confinement tine. A lower bound on $s^{\text {eff }}$ is obtained by Ignoring self-aputterting; in this case seff $=0.043$. Eaed on a value of $\tau$ - 60 (from Ref, 2 results) the average carbon concentration would reach $72 \%$ 


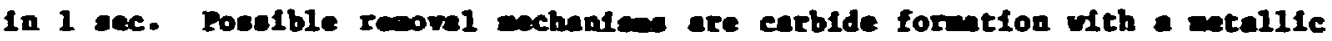
flret wall and trawport of corbon into the popins duct. Bowever in IrCx, sans 902 of the pland cutflux iplages on the liniter, thus ifnting the effect of these recoval wehantese. Informetion on earbon behafior in precent day mechines is hard to weese becues thase wchines have colder adges, shorter pulses, and leas extenive 11niter eurfaces than ICK. An encouragins result howerer is the obervation of redeposited carbon in ASTA. (5)

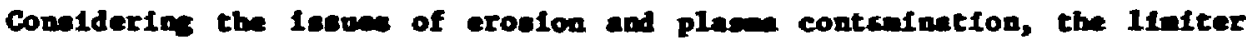
1. scceptable under the reference condition. A 1 -ce thick carbon contins (cladding) would lant abont four wecke of full operation. This translates Into about $10 \mathrm{gr}$ of real tes operation at $2 \mathrm{~s}$ arallability or about the proposed life of TrCx. The liatter would likely be changed several tines for other reasone such an experinentation and dange fron discuption.

\section{0 or a ches}

Computer runs were ade for two different edge teperatures, $\mathrm{T}_{\mathrm{e}_{0}}=50 \mathrm{eV}$, and $300 \mathrm{er}$. Other plaen paraneters were scaled accordingly. In particular,

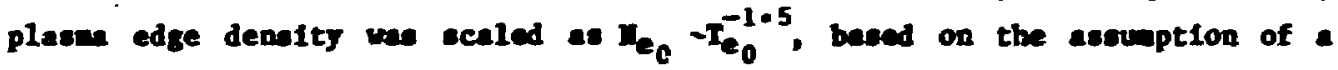
constant heat flux. The plase contenfnetion frection, and the average net eroston rate for these cases, and the reference cave, are conpared in Table 1. As shown, contanination and erosion both seale with temperature ( 1 n the ten-

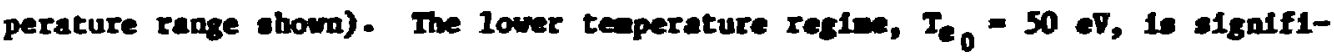
cantiy better than the reference case, for two reasons: (1) sputtering coefflcents are lower; and (2) the higher denofty reault in wore scrapeoff zone Ionization.

For a beryllin-conted 1inter, the containation results are siallar to carbon. The penk erosion, howerer, whth occure at the lending edge for berylliu is about tulce as bed. This is due to higher D-I aputterins coefficients. Berflliu any have the advantage of better redepoaition properties than carbon.

For the reference case, average impingewent angles for low on the liniter are taken as 60 des from the normal. A case (not shown) wa run with the average anglee set to 0 des (nomel incidence). This reduced the net eruston rate and contanination fraction by about a factor of two. 
Table 1. Performance Comparison of Different Materials and Edge Conditione

\begin{tabular}{|c|c|c|c|c|}
\hline $\begin{array}{l}\text { Lindter Coating } \\
\text { Material }\end{array}$ & $\begin{array}{c}\text { Edge Electron } \\
\text { Tenperature } \\
T_{e_{0},} \text { eV }\end{array}$ & $\begin{array}{c}\text { Peak Net } \\
\text { Erosion Rate, } \\
\text { ca/yr }\end{array}$ & $\begin{array}{l}\text { Platma } \\
\text { Conturinatign } \\
\text { Fraction }\end{array}$ & Cowente \\
\hline Carbon & 117 & 16 & 0.018 & Reference case. \\
\hline Carbon & 50 & 4 & 0.0043 & \\
\hline Carbon & 300 & 62 & 0.039 & \\
\hline Bery111un & 117 & 29 & 0.021 & $\begin{array}{l}\text { Peak eroston occurs at } \\
\text { leading edge. }\end{array}$ \\
\hline $\begin{array}{l}\text { Carbon - with chanical } \\
\text { sputtaring }\end{array}$ & 117 & 42 & 0.024 & $\begin{array}{l}\text { Grose eputter rates ere } \\
\text { very high. }\end{array}$ \\
\hline Tungseten & 50 & 4 & $0.77 \times 10^{-3}$ & \\
\hline
\end{tabular}

At etart of ecrapeoff.

$b_{\text {At }} t=0$. 
The effect of chemical spatertios of carbon was also exhined. The aethod described ia Ref. 1 we ued to nodal chmical aputterins. Although the contenination fraction bown is reasonable, the revelte for cheafeal sputtering are very speculatira due to very hifh grose oputter rates and concerno about stickins proparties.

The use of adiu and hith-z enterials would requite loner edge tempera-

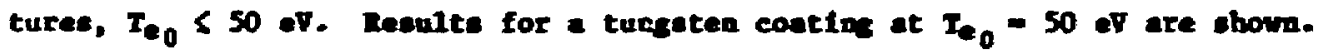
The contealnation fraction is olgnificant at this temparature but decreases rapldis for lower temperaturee.

\section{0 conctustons}

Erosion and plana contemination calculation were ade for the MCKpupped 1intier. The reference case is a carbon coatios with a modorate plasa edge temperature. Dased on these results, a pupad lifiter wil have acceptable sputtering perforance for a near tern igation device ouch a TCx. Both plasea contalnation and erosion appear to be aceeptable. In Inportant Issue for the use of carbon, bowrver, is to sesese the atfekins properties of redeposted aterial. Barjiliu provides an inportant alternative to carbon In the event that chealcal sputterin andor poor redeposition properties are obtained for carbon. Lower edge temperatures than the -100 ef predicted are not necesaary for low-z continge but would certainly be beneficial. Hediu and high-Z contfigs offer another alternative, if edge temperatures of $\leq 50 \mathrm{eT}$ are obtainable. 
1. 3. H. Brooks, Fucl. Technol.frusion 4, 33 (1983).

2. C. D. Doley, -Transport of Reutral Atom and Noleculee In IFG," SIxth International Conf. on Plasan Surface Interection in Controlled Fusion Devices, Ingoya, Japan (1984), to be published.

3. J. H. Brooks, and M. Kaninaky, "Influence of Erosion and Redeprostiton Processes on the Iffetine of Impurity Control Components:. An Aasesment for ThC Coatinge, $-\mathrm{J}$. Nucl. Nater., to be published.

4. H. X. Terry, et al., "Transport Code Analysis of Sowe Aspects of Inpurity Control in Reactor Grade Toknak Plasine," Fusion Technol., to be published.

5. J. B. Roberto, et al., The Dse of Isotopically Enriched Carbon Probes for Erosion/Deposition Measuresents in the ASDAX Divertor, " Sixth International Conf. on Plasa Surface Interactions in Controlled Pusfon Devicee, Nagoya, Japan (198h), to be published. 
Distribution for AU/TPP/ni-191

Interne1:-

C. Baker

C. Boley

J. Brooke (10)

F. Cafasao

I. Cha

R. Clemer

D. Ehst

R. Evans

P. Finn

Y. Gohar

L. Greenwood

D. Gruen

A. Hassanein
C. Johneon

J. Juns

H. Toninoky

S. Kin

R. Juston

L. Lesage

I. Lfu

B. Loont:

S. Mafundar

v. Maroni

R. Hettas

B. Misra

J. Boren

R. Mygren
1. Praes

J. Roberte

G. Rosenberg

D. Satth

H. Steven

D. Sze

L. Turner

AII Ratent Dept. PP Progran (15)

AIL Contract File

AIL LAbraries (2)

IIS F1lee (6)

\section{Externa1 :}

DOE-TIC, for diatribution per UC-20 (107)

Hanager, Chicago Operation Office, DOE

Special Comittee for the Furion Progran:

S. Baron, Duro d Roe, Ire., Oredell, hJ

H. K. Forsen, Dechtel Group, Inc., San Francisco, CA

J. Maniscalco, TRH, Inc., Redondo Beach, CA

G. H. Miley, University of Illinote, Urbans

P. J. Reardon, Brookhaven National Iaboratory

P. H. Rutherford, Princeton Placan Fhysice Laboratory

D. Stelaer, Renuselier Polytechnic Inotitute

R. R. Syon, Univereity of Wisconsin-iadison

K. Thomasen, Laurence Livernore National Laboratory

J. Cecch1, Princeton Plaene Fhyalca Laboratory

J. Schnidt, Princeton Plasea Physica Leboratory

D. Post, Princeton Plasia Physics Laboratory 
ABSTRACT $\ldots \ldots \ldots \ldots \ldots \ldots \ldots \ldots \ldots \ldots \ldots \ldots \ldots \ldots \ldots \ldots \ldots \ldots \ldots \ldots \ldots \ldots \ldots \ldots \ldots \ldots \ldots \ldots \ldots$

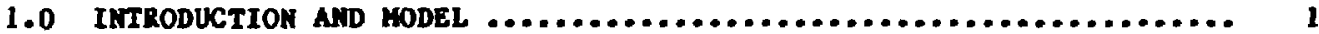

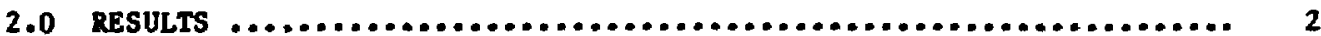

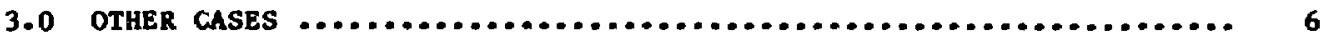

4.0 ConCLUSIOHS $\ldots \ldots \ldots \ldots \ldots \ldots \ldots \ldots \ldots \ldots \ldots \ldots \ldots \ldots \ldots \ldots \ldots \ldots \ldots \ldots \ldots \ldots \ldots \ldots$

REFERENCES.$\ldots \ldots \ldots \ldots \ldots \ldots \ldots \ldots \ldots \ldots \ldots \ldots \ldots \ldots \ldots \ldots \ldots \ldots \ldots \ldots \ldots \ldots \ldots \ldots \ldots \ldots \ldots$

\section{LIST or FIGUNBs}

No.

Title

1 LiEicar shape at initial startup and after four weeks of continuous operation.

2 Net growth rate of the limiter carbon coating at initial startup and after four weeks of continuous operation.

3 Limiter heat flux at initial startup and after two and four weeks of continuous operation.

\section{LIST or TALES}

No.

Title

1 Performance Comparison of Different Haterials and Edge Conditions 